\title{
Sources and health risk assessments of nitrate in groundwater, West of Tahta area, Sohag, Egypt
}

Geology Dept. Faculty of Science, Sohag University, 82524 Sohag, Egypt; *Corresponding author, E-mail: mostafa.redwan@science.sohag.edu.eg

(Received: October 23, 2019; Revised accepted: January 25, 2020)

https://doi.org/10.18814/epiiugs/2020/020048

Due to natural and anthropogenic human activities in arid and semi-arid regions, groundwater will continuously suffer from severe contaminations such as increases in nitrate levels. Groundwater contamination poses serious threats to the environment and human health. In the current study, 23 groundwater samples were collected from the desert zone around the wastewater treatment plant west of Tahta area, Sohag, Egypt. The samples were chemically and bacteriologically analyzed to quantify the sources and potential risk of nitrate in groundwater to the health of adults, children and infants. The nitrate showed wide spatial variability in the studied area, with values going from 0.38 up to $59 \mathrm{mg} / \mathrm{L}$. Based on the bacteriological, principal component, $\mathrm{NO}_{3}^{-}$and $\mathrm{NO}_{3}{ }^{-} / \mathrm{Cl}$ analyses, nitrate in the south-western parts around the wastewater treatment plant developed from the sewage contamination while the northeastern and southern parts are mainly due to contamination from the agricultural activities and organic wastes. The non-carcinogenic hazard quotients (HQ) values of $78 \%$ of infants, $70 \%$ children and $4 \%$ of adults were higher than the safety level (i.e., $H Q s>1$ ), suggesting severe health effects on human health. Proper management of wastewater disposal activities and application of fertilizers are required to reduce groundwater contamination in Egypt and globally.

\section{Introduction}

Groundwater is an essential source of water for drinking, agriculture and industrial purposes in arid and semi-arid regions worldwide (Liu et al., 2010; Li, 2016). As a result of the rapid increase in population and urbanization, many environmental problems including groundwater pollution have been evolved (Burri et al., 2019; Shaharoona et al., 2019). Recently, many anthropogenic processes are responsible for groundwater contamination such as $\mathrm{Ca}, \mathrm{F}, \mathrm{PO}_{4}, \mathrm{NO}_{3}$, $\mathrm{NH}_{4}, \mathrm{SO}_{4}$ (Aiuppa et al., 2003; Redwan and Abdel Moneim, 2016a; Arslan, 2017; Burri et al., 2019) and heavy and trace metals such as $\mathrm{Al}, \mathrm{As}, \mathrm{B}, \mathrm{Ba}, \mathrm{Fe}, \mathrm{Co}, \mathrm{Cd}, \mathrm{Cr}, \mathrm{Cu}, \mathrm{Hg}, \mathrm{Mo}, \mathrm{Ni}, \mathrm{Se}, \mathrm{Si}, \mathrm{V}$ and $\mathrm{Zn}$ (Giammanco et al., 1998; Fu and Wang, 2011; Fu et al., 2014; Hosseini and Saremi, 2018; Kyere et al., 2018; Burri et al., 2019) . Proper manage- ment of contaminants and identifying their possible sources is vital in arid and semi-arid regions (Qasemi et al., 2018b). Disposal sites of wastewater are considered great pollution sources and can create a serious threat to the environment through direct contact with the surface water and/or groundwater (McArthur et al., 2012). Wastewater contains many dissolved organic and inorganic matters, including heavy elements such as arsenic, copper, cadmium, chromium, zinc, lead, and pathogenic bacteria (Fu and Wang, 2011; Fu et al., 2014).

Among the different contaminants, nitrate is considered as a significant ion to limit water potability (Borzi et al., 2015). Nitrate concentration in water more than $10 \mathrm{mg} / \mathrm{L}$ may be toxic to infants and may lead to stomach cancer (Wu and Sun, 2016). According to the World Health Organization (WHO), very quick health problems can be produced through drinking nitrate-rich water. Nitrate values above $50 \mathrm{mg} / \mathrm{L}$ in drinking water (WHO, 2011) can be risky to human and animal lives (Sall and Vanclooster, 2009). Nitrates degrade water quality, leading to the eutrophication and the spread of toxic algal blooms in water (Ji et al., 2017). High nitrate concentration in drinking water can raise the risk of infants' methemoglobinemia, diabetes, spontaneous abortions, cancer, thyroid gland problems, mutagenesis and teratogenesis (Wu et al., 2017). Environment Protection Agency (EPA) states that the nitrate concentration for drinking water should not exceed $45 \mathrm{mg} / \mathrm{L}$ (USEPA, 2013). Elevated nitrate or nitrite concentration showed adverse reproductive effects like abortions and many birth defects on animal (Manassaram et al., 2006).

Based on the International Agency for Research on Cancer regulations (IARC, 2010), nitrate and nitrite are treated as "probably carcinogenic to humans". As a result, drinking water contaminated by the nitrate is a severe environmental health hazard that requires special attention by the decision-makers to reduce contamination (Qasemi et al., 2018a).

Nitrate can be formed through natural fixation of nitrogen or human activities through sewage disposal, chemical fertilizers, landfills leachate, dairy products, and chemical industries, as along with organic matter nitrification processes by bacteria (Manassaram et al., 2006; Wu and Sun, 2016; Wang et al., 2018).

Few authors have investigated the groundwater potentiality and quality in the study area (Dawoud, 1997; Esam et al., 2012; Redwan and Abdel Moneim, 2016b) without giving the environmental hazards related to groundwater contamination. The aims of the current study were to (1) quantify the levels nitrate in drinking water around the wastewater treatment plant and farmlands, west of Tahta city, Sohag, 
Egypt and (2) compare the nitrate levels to the standards values of EPA, (3) determine human health impacts. The results obtained from this study regarding the nitrate sources and distribution will help the stakeholders and decision-makers for the current status and future water and/or wastewater improvement and management nationwide.

\section{Materials and Methods}

\section{Study Area Description}

The study area is situated in the desert zone west of Tahta city, west of the Nile, to the north of Sohag (about $400 \mathrm{~km}$ from Cairo) (Fig. 1). Many agricultural activities, new industrial zone and urban centers on the newly reclaimed areas can be recognized. The study area is surrounding from the west by the Eocene limestone plateau dissected by several W-E direction drainage basins with a general slope towards the agricultural areas and the River Nile. The study area belongs to the arid zone of Egypt, characterized by a dry climate with an average temperature and annual rainfall of about $23.8-24.0^{\circ} \mathrm{C}$ and $0.70-0.75$ $\mathrm{mm}$, respectively. The west Tahta wastewater treatment plant has a $35,000 \mathrm{~m}^{3}$ /day design capacity (Fig. 1), provided for about 400,000 citizens living in the Tahta city. The recycled water from the plant is used for irrigating casuarina trees for timber and firewood in an area of 4.5 $\mathrm{km}^{2}$. The increasing amounts of wastewater reach the treatment plant that exceeds the design capacity by about $10.1 \mathrm{~m}^{3} /$ day, develop wastewater ponds with a potential risk of groundwater contamination. Septic tanks and pit latrines are common onsite sanitation facilities developed in most of the villages due to the lack of wastewater treatment facilities.

\section{Geology}

The sedimentary succession of the study area ranges in age from Lower Eocene to Recent as follows (Fig. 2):

a. Thebes Formation (Lower Eocene) (Said, 1960): massive to laminated limestone with flint and marl with Nummulites $s p$. and planktonic foraminifera.

b. Muneiha Formation (Early Pliocene) (Issawi et al., 1978): thick beds of quartz and clay (montmorillonite and kaolinite) of estuarine and fluvial origin. It forms the base of the water bearing formations in the Nile Valley (Fig. 2).

c. Qena Formation (Early Pleistocene) (Said, 1981): quartzitic sand and gravel deposited in braided/ and low-moderate meandering streams. It contains heavy minerals of metamorphic origin come by the river from the Sudanese Red Sea hills (Omer, 1996). This formation forms the main water bearing zone in the study area.

d. Kom Ombo Formation (Early Pleistocene- Middle Pleistocene)
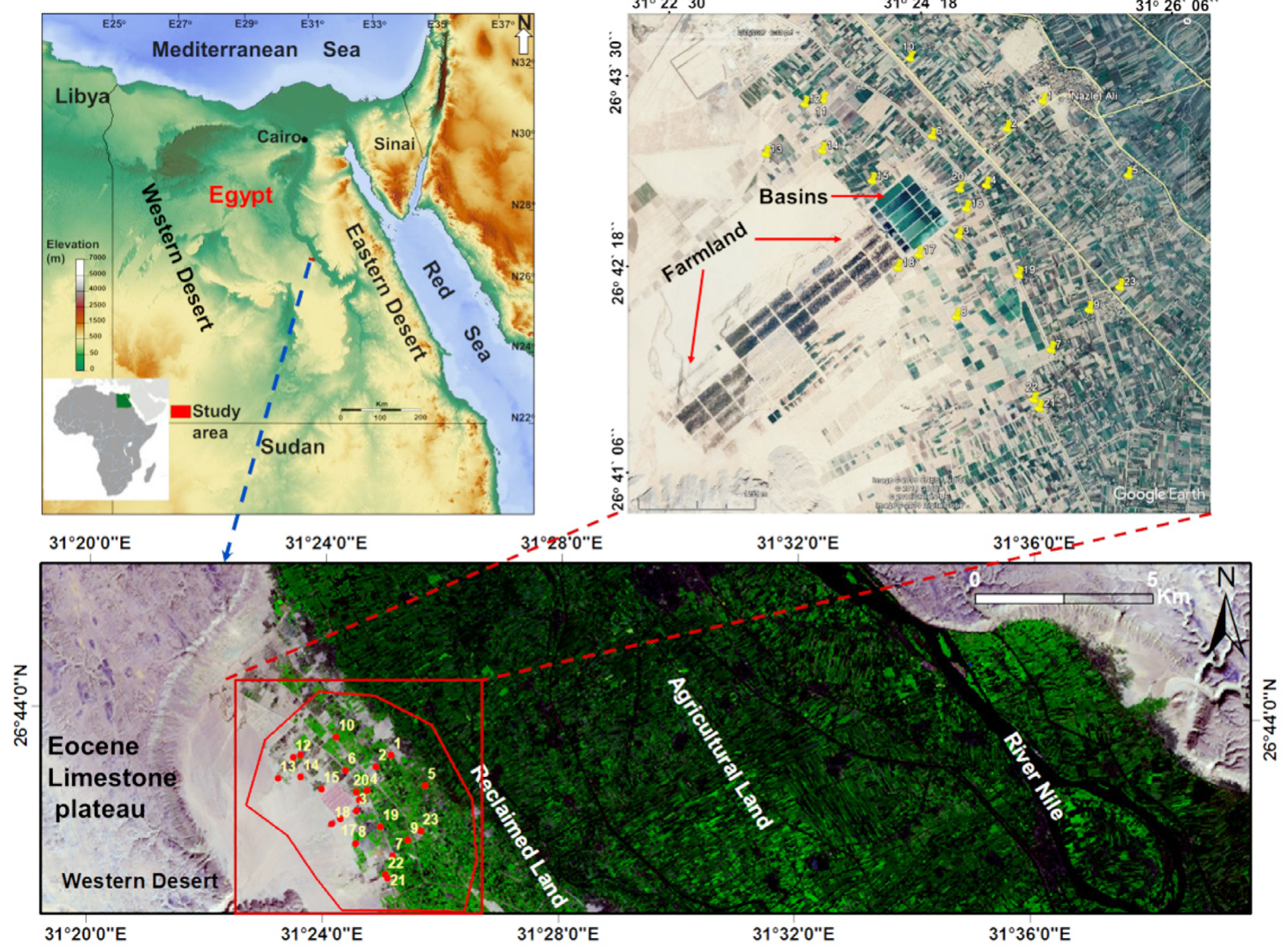

Figure 1. Location (Landsat) and Google earth maps of the collected groundwater samples in the study area. 


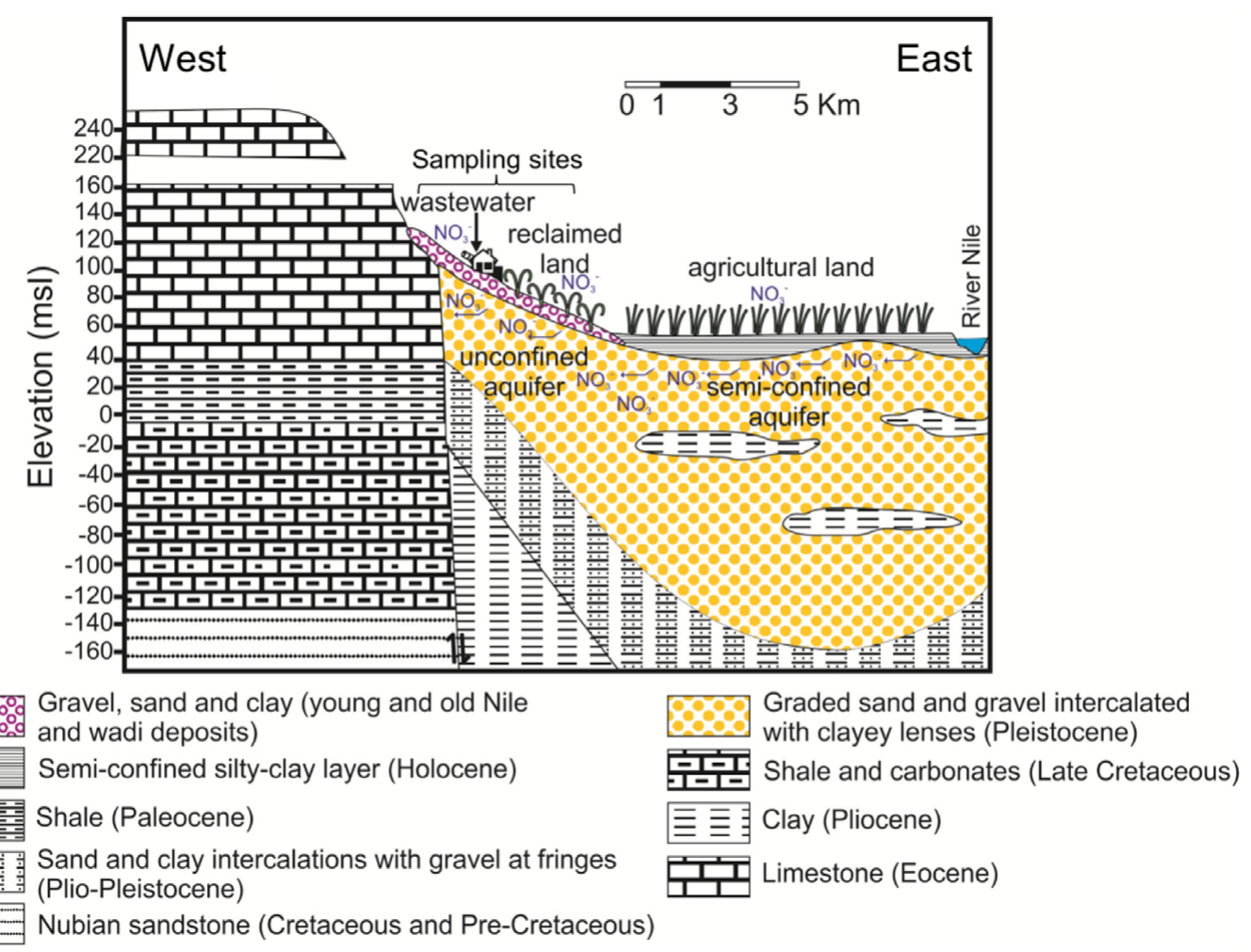

Figure 2. Cross-sectional lithological view and potential $\mathrm{NO}_{3}^{-}$pollution pathways in the study area.

(Issawi and Hinnawi, 1980): alluvial and fluvial facies gravels and sands of igneous and metamorphic origins.

e. Ghawanim Formation (Middle Pleistocene) (Omer, 1996): cross-bedded fluvial sand and gravels with conglomerate and quartzitic sandstone bands and lenses formed by the Egyptian and Ethiopian water.

f. Dandara Formation (Late Middle Pleistocene) (Said, 1975): poorly sorted sands ranging from coarse to very fine grain sizes with sediments from Ethiopia and followed by sediments from equatorial Africa. Recent flash flood wadi deposits in the area deposits are distributed on the surface of the old sediments throughout study area (Fig. 2). These deposits include alluvial deposits which composed mainly of mud and silts with sandstone intercalations and fine sand grains.

\section{Hydrogeologic Characteristics}

The groundwater aquifer is represented by the Qena Formation (Abdel Moneim, 1999) that is overlain by recent sediments (mud and silts with sand and sandstone intercalations) under unconfined conditions (Fig. 2) and towards the east changed into semi-confined aquifer of the area underlying the floodplain Nile sediments (fine sand and silt with low vertical and horizontal permeability, $<15.6 \mathrm{~m} /$ day). The aquifer thickness varies from 20 to 80 meters, and increases towards the east (i.e. the Nile cultivated lands). Groundwater levels in the study area vary from $45.5 \mathrm{~m}$ in the northern part and $53 \mathrm{~m}$ in the southern part of the area. The groundwater hydraulic gradient is generally from the west to east having value ranging between 0.0006 and 0.0016 with an average of about 0.008 . Recharge process of the Quaternary aquifer is from excess irrigation water seepage from the cultivated areas and irrigation canals and post-Eocene rainwater stored in the Pleistocene aquifer. The main groundwater flow direction is to the northwest following the topography of the floodplain and discharge. The second flow direction is west - east towards the River Nile as a result of canals recharge.

\section{Sampling and Analysis}

Sampling in 23 farm wells around the west of Tahta wastewater treatment plant and farmlands was collected to measure groundwater nitrate contamination. No samples were collected far away from the treatment plant in the old agricultural lands due to the presence of a residential community with private pit latrines. The agricultural crops in the study area are mainly wheat, corn, alfafa, barley and onion. Field sampling was carried out during June 2016 using 300 pre-cleaned polyethylene plastic bottles. After pumping out water from the wells for about 3-4 min to remove any stagnant water in the pipes, the bottles were cleaned three times with the sampled water before filling it with the representative samples to exclude any external contamination. The groundwater samples were transported to the laboratory to be directly analyzed for nitrate, sulfate, and chloride concentrations using Dionex ion chromatography (IC). Carbonates were measured using titration method (Stumm and Morgan, 2012). The bacteriological analysis was carried out using the multiple tube fermentation technique. Methods precision was evaluated using calibrated standard solutions. Blanks and triplicated standard samples were applied for quality control and quality assurance (QC/QA). The sampling process and analytical techniques used were based on standard methods for the testing of Water and Wastewater (APHA, 2012). 


\section{Statistical Analysis}

Statistical analyses of the groundwater hydrochemistry data were performed on normalized data using the statistiXL software (www.statistixl.com/) in order to quantify the inter-correlation between the different variables. The Kaiser criterion is used to set the maximal extracted factors numbers with eigenvalues higher than 1 (Lawrence and Upchurch, 1982; Costello and Osborne, 2005). The principal component analysis (PCA) loading values $>0.75,0.75-0.5$, and $<0.5$ indicate a strong, moderate and weak respectively.

\section{Human Health Risk Assessment}

Human health risk assessment is "the process to estimate the nature and probability of unfavorable effects to humans due to chemicals exposure in a contaminated environment, now or in the future" (Ruiz et al., 2013). Health risk assessments could play a key role in health promotion and disease prevention both at an individual and a population level (Orlando and $\mathrm{Wu}, 2018$ ). Human health risks are classified as non-carcinogenic (induced by non-carcinogens) risk and carcinogenic (induced by carcinogens) risk (Keramati et al., 2018; Miri et al., 2017). The chronic daily intake (CDI), hazard quotient (HQ) of single contaminant and the health risk index (HI) for numerous contaminants are key parameters that can be used for the quantification of health risks (Keramati et al., 2018). In the current study, we quantified the non-carcinogenic risk as a result of nitrate intake in drinking water for three age groups, adults, children, and infants based on the non-carcinogenic hazard quotient model proposed by the United States Environmental Protection Agency (USEPA, 2013). The direct ingestion, skin contact, and inhalation are the viable routes of contaminants exposure in water (Liang et al., 2016; Wang et al., 2011).

The CDI (chronic daily intake) $(\mathrm{mg} / \mathrm{kg} /$ day) nitrate level in water can be computed based on the following equation (Liang et al., 2013; Miri et al., 2018):

$$
C D I=\frac{C w \times D I \times E F \times E P}{B W \times A T}
$$

Where CDI is the average daily dose ( $\mathrm{mg} / \mathrm{kg} /$ day), $\mathrm{Cw}$ is the contaminant concentration in drinking water $(\mathrm{mg} / \mathrm{L})$, DI is human daily water intake (L/d), EF is the frequency of exposure (day/year), EP is the mean exposure duration (years), BW is the mean weight of the body $(\mathrm{kg})$, and AT is the mean time (day). The different parameters used for the health risk assessment are given in Table 1.

The non-carcinogenic hazard quotients (HQ) risks are the ratio between the potential exposure to a contaminant and the level at which no negative effects are expected. The non-carcinogenic HQ risk can be quantified by the following equation (Lim et al., 2008; Radfard et al., 2018):

$$
H Q=\frac{C D I}{R f D}
$$

Where RfD is the reference nitrate dosage in $\mathrm{mg} / \mathrm{kg} /$ days which is equal to $1.6 \mathrm{mg} / \mathrm{kg}$ /days based on the USEPA (2013).

According to the USEPA regulations, $\mathrm{HQ}<1$ represent unlikely harmful non-carcinogenic health impact by nitrate to the individual, whereas $\mathrm{HQ} \geq 1$ denote a harmful impacts may occur (Huang et al., 2018; Jafari et al., 2018).

\section{Results and Discussion}

\section{Concentrations and Origin of Nitrate in Wells}

With a growing population, many countries like Egypt need adequate quantities of acceptable quality water for sustaining, human wellbeing, livelihoods and socio-economic development. Pollution is becoming one of the main threats to the availability of water resources. Improper management due to lack of financial limits and recommendations from the scientific communities in developing countries lead to severe problems in drinking water quality that needs detailed understanding to protect groundwater resource. Egypt is characterized by arid climate; water resources in many areas are scarce and depend mainly on the groundwater. Many factors are affecting the groundwater aquifers due to the overexploitation, extensive fertilizers and improper treated wastewater disposal (Shamrukh et al., 2001; Ahmed and Ali, 2011; Redwan et al., 2016).

Nitrate in groundwater may result from sewage disposal, livestock, agricultural fertilizers, parks, lawns, gardens and natural occurring nitrogen sources (Nemčić-Jurec and Jazbec, 2017; Wei et al., 2017) (Fig. 3). The parameters $\mathrm{Cl}^{-}, \mathrm{SO}_{4}{ }^{2-}, \mathrm{Ca}^{2+}$ and particularly $\mathrm{NO}_{3}{ }^{-}$are precisely the significant ions of nitrogen fertilizers which include ammonium chloride $\left(\mathrm{NH}_{4} \mathrm{Cl}\right)$, ammonium sulfate $\left.\left(\mathrm{NH}_{4}\right)_{2} \mathrm{SO}_{4}\right)$, ammonium nitrate $\left(\mathrm{NH}_{4} \mathrm{NO}_{3}\right)$ and calcium nitrate $\left(\mathrm{Ca}\left(\mathrm{NO}_{3}\right)_{2}\right)$ (Wei et al., 2017). $\mathrm{NH}_{4}{ }^{+}$ions are difficultly preserved in soils, some of its ions are absorbed by plant roots and soils, and others are transformed into $\mathrm{NO}_{3}^{-}$by nitrification (Mekala and Nambi, 2016), as shown in Fig. 3.

The bacteriological impacts on groundwater samples showed a positive indication of the presence of fecal coliform bacteria ( $52 \%$ of samples) (Fig. 4) started from the disposal site and extended northeast about $2.0 \mathrm{~km}$ following the local topography, except for wells no. 1,2,

\begin{tabular}{|c|c|c|c|c|}
\hline \multirow{2}{*}{ Risk exposure factors } & \multicolumn{3}{|c|}{ Values for groups } & \multirow[b]{2}{*}{ Unit } \\
\hline & Adults (age >19) & Children $(6>$ age $>12)$ & Infants (age $<1)$ & \\
\hline$C_{\mathrm{w}}$ & & & & $\mathrm{mg} / \mathrm{L}$ \\
\hline DI & 2 & 1.5 & 0.8 & $\mathrm{~L} /$ day \\
\hline$F$ & 365 & 365 & 365 & days/year \\
\hline EP & 40 & 10 & 1 & years \\
\hline BW & 70 & 20 & 10 & $\mathrm{~kg}$ \\
\hline AT & 14,600 & 3650 & 365 & days \\
\hline
\end{tabular}

Table 1. Parameters applied for health exposure assessment in water (Qasemi et al., 2018a) 


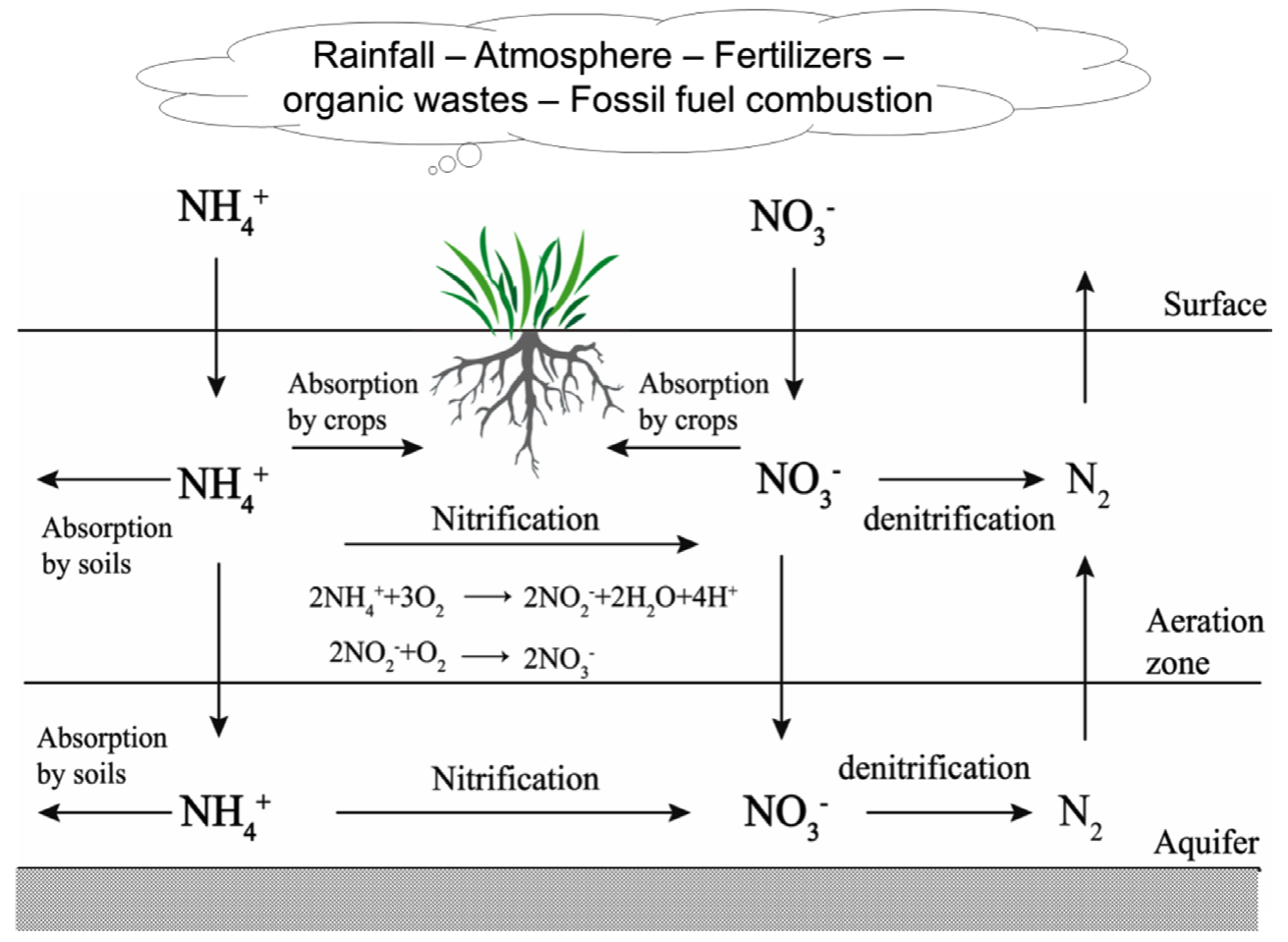

Figure 3. Scheme for nitrogen cycle and transformation (modified after Wei et al., 2017).

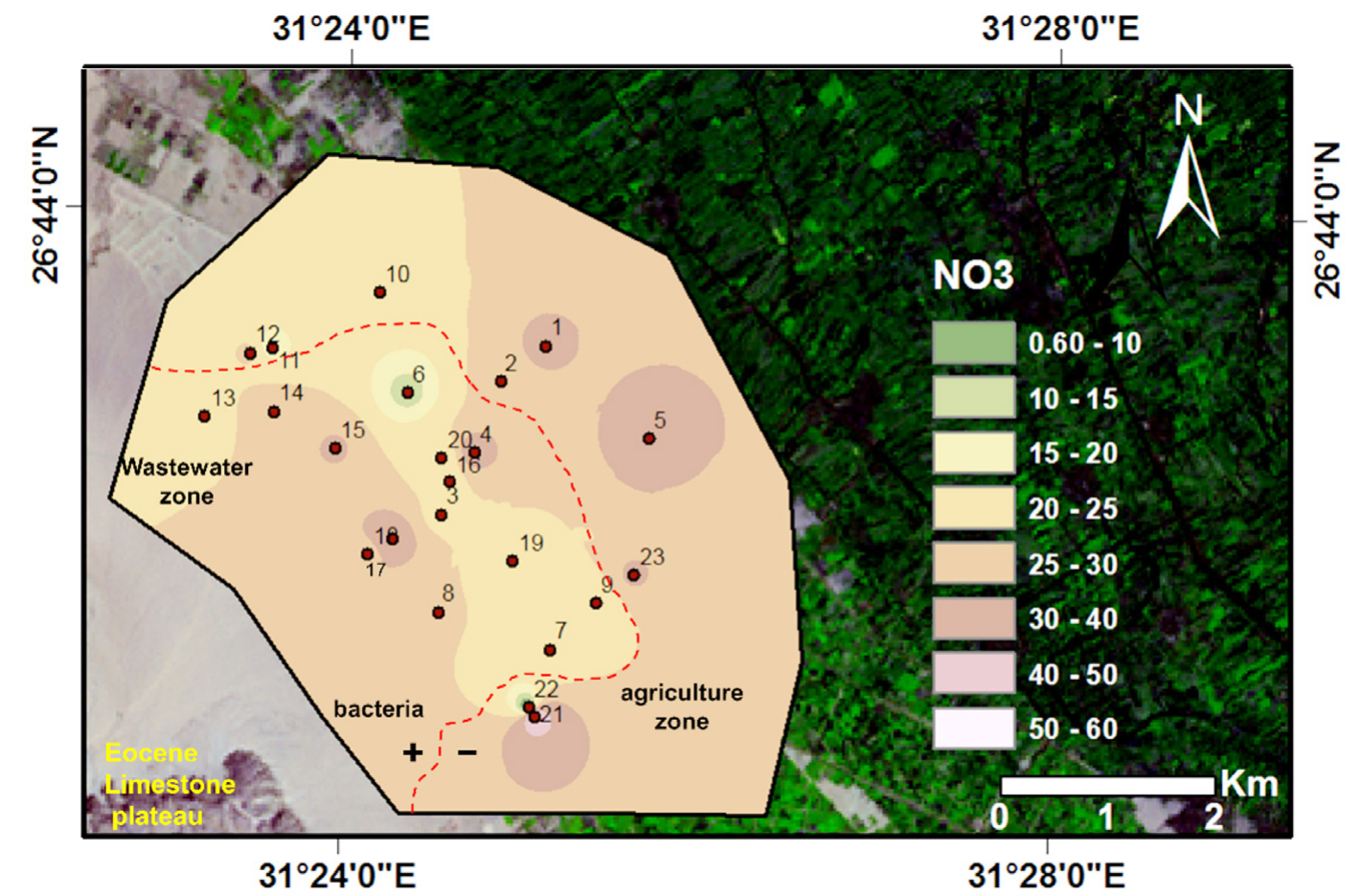

Figure 4. Aerial view and potential $\mathrm{NO}_{3}^{-}$pollution sources. The signs $+/-$indicate the presence/non-presence of coliform bacteria.

$5,9,10,11,12,18,21,22$ and 23 . The nitrate concentrations showed wide spatial variability in farm wells ( 23 wells) of the studied area, with values going from 0.38 up to $59 \mathrm{mg} / \mathrm{L}$ with a mean concentration of $24.8 \mathrm{mg} / \mathrm{L}$. In the current study, it is clearly recognized that all the investigated farm wells had nitrate values beneath the EPA standard for nitrate, except one site with a nitrate concentration of $59 \mathrm{mg} / \mathrm{L}$
(Figs. 4 and 5).

$\mathrm{Cl}^{-}$is a good indicator of sewage contamination of groundwater as it is not dependent on the physical, chemical and microbiological processes (Fig. 6) (Xing and Liu, 2016; Wei et al., 2017; Meghdadi and

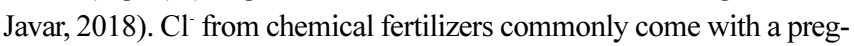
nant increase in $\mathrm{NO}_{3}^{-}$concentrations, whereas higher $\mathrm{Cl}^{-}$concentrations 


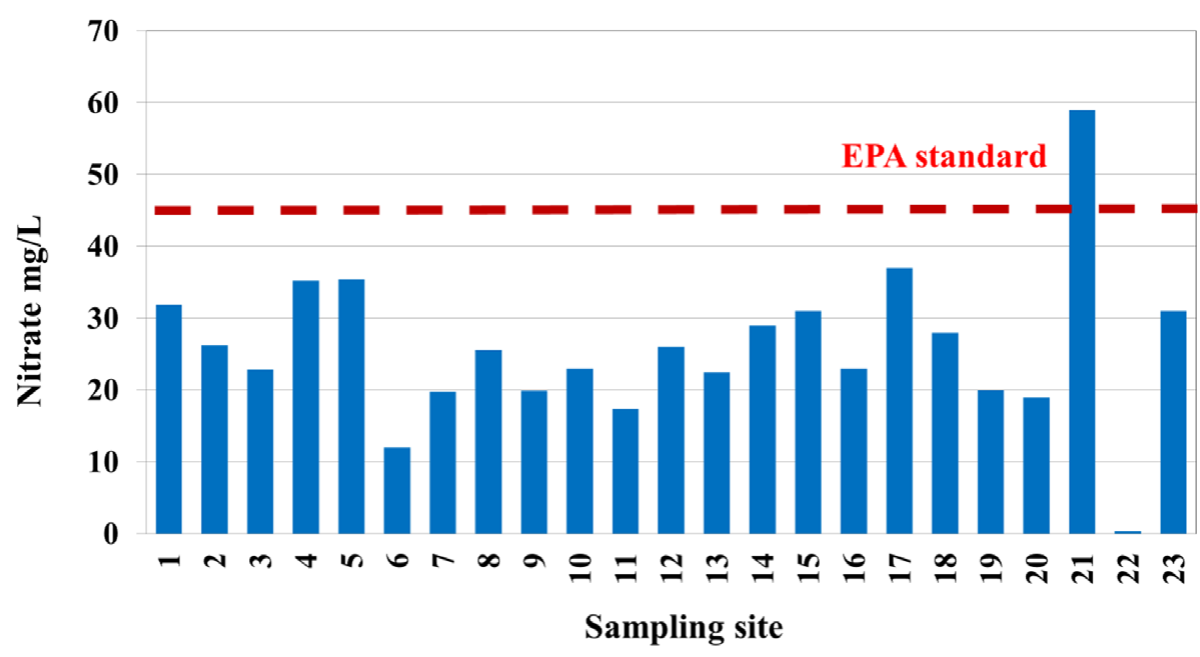

Figure 5. Mean nitrate concentrations ( $\mathrm{mg} / \mathrm{L})$ in groundwater samples collected from the studied area.

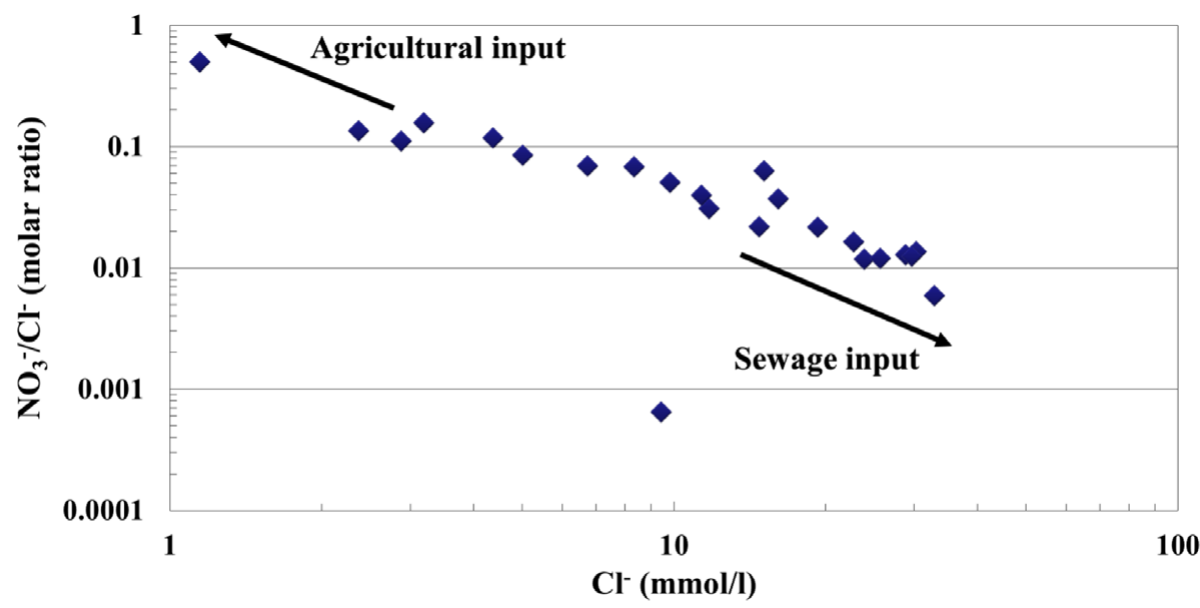

Figure 6. Variations in $\mathrm{NO}_{3}^{-} / \mathrm{Cl}$ molar ratios with $\mathrm{Cl}^{-}$molar concentrations in groundwater samples.

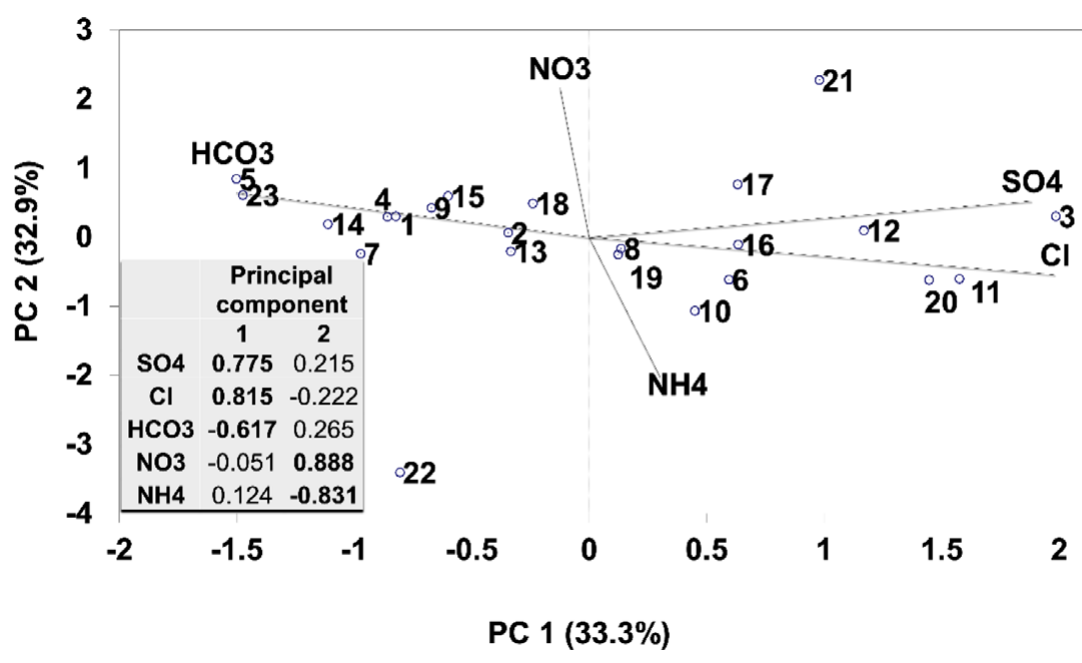

Figure 7. The PCA results for 23 hydrochemical data set with loading plot.

with relatively low $\mathrm{NO}_{3}^{-}$often indicate domestic sewage and industrial wastewater as well as livestock effluent. As a result, the ratio of $\mathrm{NO}_{3}^{-} / \mathrm{Cl}^{-}$(Fig. 6) can offer detailed information for the study of $\mathrm{NO}_{3}^{-}$ sources in groundwater (Chen et al., 2009; Xing and Liu, 2016). Groundwater samples with high $\mathrm{Cl}^{-}$contents and low $\mathrm{NO}_{3}^{-} / \mathrm{Cl}^{-}$ratios were primarily polluted by sewage from the wastewater plant or from livestock effluent. The highest ratios were around the wastewater treatment plant. Groundwater samples with high $\mathrm{NO}_{3}{ }^{-}$and low $\mathrm{Cl}^{-}$concentrations may relate to the agricultural input. Figs. 1 and 4 also show the study area classified into the agriculture land, reclaimed land and the desert zone. By combining the distribution of $\mathrm{NO}_{3}^{-}$concentrations of groundwater samples, it can be concluded that the samples with high concentrations were mainly distributed toward the reclaimed and the agricultural land and desert zone around the wastewater treatment plant.

This is indicated by using the principal component analysis (PCA) (Fig. 7). The first two eigenvectors and the loading plot of the varimax rotated component are depicted in Fig. 7. The first two PCs, $33.3 \%$ and $32.9 \%$, covered more than 66 percent of the total variance in data. The first loading value showed the highest correlation between $\mathrm{Cl}^{-}, \mathrm{SO}_{4}^{2-}$ of 0.815 and 0.775 respectively. The concentration of $\mathrm{SO}_{4}^{2-}$ is relatively limited compared with $\mathrm{Cl}^{-}$due to its the small solubility (Wei et al., 2017). However, $\mathrm{Cl}^{-}$and $\mathrm{SO}_{4}{ }^{2-}$ typically increases in groundwater as a result of the application of chemical fertilizers (McQuillan, 2004; Mekala and Nambi, 2016). Other sources of $\mathrm{Cl}^{-}$include manure slurry contamination, e.g. from dairy farmlands (McQuillan, 2004) and leaching of marine Pliocene clay that form the base of the aquifer (Redwan and Abdel Moneim, 2016). In addition, $\mathrm{SO}_{4}{ }^{2-}$ ions can originate from gypsum and/or anhydrite dissolution. $\mathrm{HCO}_{3}^{-}$showed high negative loading that refers to the water-rock interaction due to carbonate-silicate rock dissolutions in the study area aquifer (Redwan and Abdel Moneim, 2016b). The high independence of $\mathrm{Cl}^{-}$on nitrate with a negative loading of nitrate $(-0.051)$ indicate different sources in groundwater (Fig. 7). The second loading value of the highest positive value of $\mathrm{NO}_{3}^{-}$, the negative $\mathrm{NH}_{4}^{+}$loading value of -0.831 could be described by the natural attenu2.5 ation process of nitrate through denitrification process in groundwater contaminated by sewage effluents (Rivett et al., 2008). From the data it can be concluded that nitrate in the southwestern parts around the wastewater treatment plant developed from the sewage contamination and the north-eastern and southern parts due to contamination from the agricultural activities and organic wastes (animal manure) (Fig. 4). 


\section{Human Health Risk Assessment}

\section{Estimation of Chronic Daily Intake (CDI)}

So far, no investigation was carried out in the studied area to estimate the toxic load induced by the water contaminant, especially the nitrate non-carcinogenic impacts in groundwater. To quantify the health risk in the groundwater samples, nitrate was used taken to estimate the non-carcinogenic risk. Nitrate transformation into nitrite

Table 2. Chronic daily intake (CDI, $\mathrm{mg} / \mathrm{kg} /$ day) values for three age groups

\begin{tabular}{cccc}
\hline \hline S. No. & CDI adults & CDI children & CDI infants \\
\hline 1 & 0.91 & 2.39 & 2.55 \\
2 & 0.75 & 1.97 & 2.10 \\
3 & 0.65 & 1.71 & 1.83 \\
4 & 1.01 & 2.64 & 2.82 \\
5 & 1.01 & 2.66 & 2.83 \\
6 & 0.34 & 0.90 & 0.96 \\
7 & 0.57 & 1.49 & 1.58 \\
8 & 0.73 & 1.92 & 2.05 \\
9 & 0.57 & 1.49 & 1.59 \\
10 & 0.66 & 1.73 & 1.84 \\
11 & 0.50 & 1.31 & 1.39 \\
12 & 0.74 & 1.95 & 2.08 \\
13 & 0.64 & 1.69 & 1.80 \\
14 & 0.83 & 2.18 & 2.32 \\
15 & 0.89 & 2.33 & 2.48 \\
16 & 0.66 & 1.73 & 1.84 \\
17 & 1.06 & 2.78 & 2.96 \\
18 & 0.80 & 2.10 & 2.24 \\
19 & 0.57 & 1.50 & 1.60 \\
20 & 0.54 & 1.43 & 1.52 \\
21 & 1.69 & 4.43 & 4.72 \\
22 & 0.01 & 0.03 & 0.03 \\
23 & 0.89 & 2.33 & 2.48 \\
\hline
\end{tabular}

after ingestion (Swann, 1975) is the main cause of toxicity as nitrite can oxidize hemoglobin to methemoglobin, which cannot bind oxygen. If oxidation overthrows the protective reduction capacity of the cells, methemoglobin accumulation (methemoglobinemia) will exist (Jaffe, 1981). Drinking water represents about $<3-21 \%$ of the average adult intake of nitrate, other nitrate sources include vegetables and meat in the form of sodium nitrite (Jaffe, 1981). Also, nitric oxide can be oxidised in several dietary products into nitrate (Wogan et al., 1995). Higher dietary nitrate consumption increases the nitrate formation in case there is simultaneous exposure to nitro-satable drugs, which have nitrite substrate (Brender et al., 2004).

The CDI nitrate data and the calculated HQ values in groundwater from the investigated area via ingestion contact route were shown in Table 2 and Fig. 8, respectively. The CDI values for groundwater samples were ranged as 0.01-1.69 (mean 0.74), 0.03-4.43 (mean 1.94) and 0.03-4.72 (mean 2.07) $\mathrm{mg} / \mathrm{kg} / \mathrm{day}$ for adults, children, and infants, respectively. The significant exposure ways for nitrate in groundwater exist through ingestions.

\section{Estimation of Non-carcinogenic Risk Levels of Nitrate}

Hazard quotient (HQ) analysis model was used to appraise the noncarcinogenic risk in the groundwater of the study area based on the US Environmental Protection Agency methodology (USEPA, 2013). Adults, children and infants age groups were used to quantify the HQ due to ingesting the nitrate from groundwater.

The HQ values in the investigated area were in ranges of $0.01-1.05$, $0.02-2.77$ and $0.02-2.95$ with mean values of $0.44,1.16$, and 1.24 , for adults, children and infants, respectively. Generally, HQ values higher than 1 are considered of harmful health impacts, whereas values less than 1 are considered to be safe. The HQ values of $78 \%$ of infants, $70 \%$ children and $4 \%$ of adults were higher than the safe level (i.e., $\mathrm{HQs}>1$ ), indicating that nitrate in groundwater would have serious health effects on these ages. Infants are obviously the most vulnerable age group to nitrate exposure.

Over the past years, various studies have used nitrate for groundwater contamination assessment. Qasemi et al. (2018a) identified in arid and semi-arid areas in villages of Azadshahr, northeastern Iran about $7 \%$ of the villages exceeds the EPA standard concentration for nitrate. In Prince Edward Island, Canada, $6 \%$ of domestic wells showed nitrate concentration higher than the WHO guideline (Savard, 2016); in Jinghui canal irrigation area of the loess region, northwest China, $50 \%$ of the groundwater samples crossed the drinking water standard for nitrate (Zhang et al., 2018).

Due to the increased population in developing countries, especially in arid and semi-arid areas, the excessive dependence on groundwater resources by local communities in villages for their daily water needs is enormously increased. Thereto, disposal activities and domestic sewage in the contaminated villages and intensive agrochemicals activities by using nitrogen ferSampling site $\begin{aligned} & \text { Figure 8. Hazard quotient (HQ) values for nitrate in groundwater samples collected tilizers after the construction of the Aswan High } \\ & \text { from the studied area. }\end{aligned}$
dam and pesticides leached downward into from the studied area. 
shallow groundwater by the infiltrated irrigation water, wastewater disposal activities and domestic sewage. The $\mathrm{NO}_{3}{ }^{-}$from wastewater and agricultural fertilizers diffused slowly in the shallow groundwater system due to the low permeability of subsurface strata and scarcity of raining events. Due to the slow average rate of infiltration and the recent age of the wastewater treatment plant only the shallow groundwater aquifers will be affected and the deeper aquifers require long time to response to changes at the surface regarding wastewater disposal and agricultural practices. This is evidenced by Huang et al. (2013) that there was a time lag up to hundreds of years between land use changes and groundwater quality response, due to the buffering capacity of the relatively thick unsaturated zone. With time, the area of $\mathrm{NO}_{3}^{-}$pollution will expand in the shallow aquifers. Therefore, effective policies to prevent, remediate and monitor the non-point source contamination of nitrate are required. The current work needs collaboration from the medical science sectors to link the groundwater contamination to the actual community diseases due to groundwater contamination. Future research may involve continuous monitoring of groundwater that is vulnerable to various contaminations to provide useful assessment information to the authorities.

\section{Conclusions}

In the area West of Tahta, Sohag, Egypt, the nitrate concentrations were below the maximum permissible concentrations of $45 \mathrm{mg} / \mathrm{L}$ proposed by the USEPA, except in one site. Groundwater samples showed a positive indication of the presence of fecal coliform bacteria (52\%) started from the disposal site and extended northeast following the local topography. The nitrate concentrations showed wide spatial variability in farm wells of the studied area, with values going from 0.38 up to $59 \mathrm{mg} / \mathrm{L}$ with a mean concentration of $24.8 \mathrm{mg} / \mathrm{L}$. From the bacteriological, principal component, $\mathrm{NO}_{3}^{-}, \mathrm{NO}_{3}^{-} / \mathrm{Cl}^{-}$data evaluation, it can be concluded that nitrate in the south-western parts around the wastewater treatment plant developed from the sewage contamination and the north-eastern and southern parts due to contamination from the agricultural activities. The HQ values of $78 \%$ of infants, $70 \%$ children and $4 \%$ of adults were higher than the safety level (i.e., HQs $>1$ ), suggesting severe health effects on human health. Wastewater disposal activities and application of fertilizers are main the sources of nitrogen in waters in the area West of Tahta, which require proper management. It is prohibited to use untreated wastewater to irrigate the croplands in order to reduce the risks of harmful effects on health.

\section{Acknowledgements}

The authors sincerely acknowledge the financial support from the Geology Department, Faculty of Science, Sohag University, Egypt. Also, authors are grateful to Editor-in-Chief Prof. Dr. Jin-Yong Lee and enormous reviewers for their constructive comments and suggestions.

\section{References}

Abdel Moneim, A.A., 1999, Geoelectric and hydrogeological investiga- tion of the groundwater resources on the area to the west of the cultivated land at Sohag, Nile valley, Upper Egypt. Geological Society of Egypt, v. 43, pp. 253-268.

Ahmed, A.A., and Ali, M.H., 2011, Hydrochemical evolution and variation of groundwater and its environmental impact at Sohag, Egypt. Arabian Journal of Geosciences, v. 4, doi:org/10.1007/s12517009-0055-z.

Aiuppa, A., Bellomo, S., Brusca, L., D'Alessandro, W., and Federico, C., 2003, Natural and anthropogenic factors affecting groundwater quality of an active volcano (Mt. Etna, Italy). Applied Geochemistry, v. 18, pp. 863-882.

American Public Health Association (APHA), 2012, Standard Methods for the Examination of Water and Wastewater, 22nd ed. Washington, DC: American Water Works Association.

Arslan, S., 2017, Assessment of groundwater and soil quality for agricultural purposes in Kopruoren basin, Kutahya, Turkey. Journal African Earth Sciences, v. 131, pp.1-13.

Borzi, G.E., Garcia, L., and Carol, E.S., 2015, Geochemical processes regulating $\mathrm{F}^{-}$, As and $\mathrm{NO}_{3}^{-}$content in the groundwater of a sector of the Pampean Region, Argentina. Science of the Total Environment, v. 530531, pp. 530-531. doi:10.1016/j.scitotenv.2015.05.072.

Burri, N.M., Weatherl, R., Moeck, C., and Schirmer, M., 2019, A review of threats to groundwater quality in the anthropocene. Science of the Total Environment, v. 684, pp. 136-154. doi:org/10.1016/j.scitotenv.2019.05.236.

Brender, J.D., Olive, J.M., Felkner, M., Suarez, L., Marckwardt, W., and Hendricks, K.A., 2004, Dietary nitrites and nitrates, nitrosatable drugs, and neural tube defects. Epidemiology, v. 15, pp. 330-336.

Chen, F.J., Jia, G.D., and Chen, J.Y., 2009, Nitrate sources and watershed denitrification inferred from nitrate dual isotopes in the Beijiang River, south China. Biogeochem, v. 94, pp.163-174. doi:10.1007/s10533009-9316-x.

Costello, A.B., and Osborne, J.W., 2005, Best practices in exploratory factor analysis: four recommendations for getting the most from your analysis. Practical Assessment, Research and Evaluation, v. 10, pp. 1-9.

Dawoud, M.A., 1997, The numerical simulation for groundwater condition in West Tahta region. MSc Thesis, Faculty of Engineering, Ain Shams Univ, Cairo, Egypt.

Esam, I., Abdalla, F., Erich, N., and Hermann, M., 2012, Comparison of the Groundwater Quality in the West Tahta Area, Upper Egypt in 1989 and 2011. Journal of Environmental Protection, v. 3, 2012, pp. 14421457. doi:10.4236/jep.2012.311162.

Fu, F., and Wang, Q., 2011, Removal of heavy metal ions from wastewaters: A review. Journal of Environmental Managment, v. 92, pp. 407-418.

Fu, F., Dionysioub, D.D., and Liu, H., 2014, The use of zero-valent iron for groundwater remediation and wastewater treatment: A review. Journal of Hazardous Materials, v. 267, pp. 194-205.

Giammanco, S., Ottaviani, M., Valenza, M., Veschetti, E., Principio, E., Giammanco, G., and Pignato, S., 1998, Major and trace elements geochemistry in the ground waters of a volcanic area: Mount Etna (Sicily, Italy). Water Research, v. 32, pp. 19-30.

Hosseini, M., and Saremi, A., 2018, Assessment and estimating groundwater vulnerability to pollution using a modified DRASTIC and GODS models (case study: Malayer Plain of Iran. Civil Engineering Journal, v. 4, pp. 433-442.

Huang, T.M., Pang, Z.H., Yuan, L.J., 2013, Nitrate in groundwater and the unsaturated zone in (semi)arid northern China: baseline and factors controlling its transport and fate. Environmental Earth Sciences, v. 70, pp. 145-156. doi:10.1007/s12665-012-2111-3

Huang, Y., Teng, Y., Zhang, N., Fu, Z., and Ren, W., 2018, Human health risk assessment of heavy metals in the soil-Panaxnotoginseng system in Yunnan province, China. Human and Ecological Risk Assessment, v. 24 , pp. $1-15$.

IARC, 2010, Ingested nitrate and nitrite, and cyanobacterial peptide toxins, vol. 94. IARC Press, International Agency for Research on Cancer, LyonGoogle Scholar.

Issawi, B., Hassan, M.W., and Osman, R., 1978, Geological studies in the 
area of Kom Ombo, Eastern Desert, Egypt. Annals Geological Survey Egypt, v. 8, pp. 187-235.

Issawi, B., and Hinnawi, M., 1980, Contribution to the geology of the plain west of the Nile between Aswan and Kom Ombo. In: Close, A.E., (Ed) Loaves and Fishes. Southern Methodist University Press. Dallas, Texas, pp. 311-330.

Jafari, A., Kamarehie, B., Ghaderpoori, M., Khoshnamv, N., and Birjandi, M., 2018, The concentration data of heavy metals in Iranian grown and imported rice and human health hazard assessment. Data Brief, v. 16, pp. $453-459$.

Jaffe, E.R., 1981, Methaemoglobinaemia. Clinical Hematology, v. 10, pp. 99-122.

Ji, X., Xie, R., Hao, Y., and Lu, J., 2017, Quantitative identification of nitrate pollution sources and uncertainty analysis based on dual isotope approach in an agricultural watershed. Environmental Pollution, v. 229, pp. 586594

Keramati, H., Ghorbani, R., Fakhri, Y., Khaneghah, A.M., Conti, G.O., Ferrante, M., Ghaderpoori, M., Taghavi, M., Baninameh, Z., and Bay, A., 2018, Radon in drinking water resources of Iran: a systematic review, metaanalysis and probabilistic risk assessment (Monte Carlo simulation). Food and Chemical Toxicology, v. 115, pp. 460-469.

Kyere, V.N., Greve, K., Atiemo, S.M., Amoako, D., Aboh, I.J.K., and Cheabu, B.S., 2018, Contamination and Health Risk Assessment of Exposure to Heavy Metals in Soils from Informal E-Waste Recycling Site in Ghana. Emerging Science Journal, v. 2, 428-436.

Lawrence, F.W., and Upchurch, S.B., 1982, Identification of recharge areas using geochemical factor analysis. Ground Water, v. 20, pp. 680-687.

Li, P.Y., 2016, Groundwater quality in western China: challenges and paths forward for groundwater quality research in western China. Exposure and Health, v. 8, pp. 305-310. doi:10.1007/s12403-016-0210-1.

Liang, C.P., Jang, C.S., Chen, J.S., Wang, S.W., Lee, J.J., and Liu, C.W., 2013, Probabilistic health risk assessment for ingestion of seafood farmed in arsenic contaminated groundwater in Taiwan. Environmental Geochemistry and Health, v. 35, pp. 455-464.

Liang, C.P., Wang, S.W., Kao, Y.H., and Chen, J.S., 2016, Health risk assessment of groundwater arsenic pollution in southern Taiwan. Environmental Geochemistry and Health, v. 38, pp. 1271-1281.

Liu, X., Song, X.F., Zhang, Y.H., Xia, J., Zhang, X.C., Yu, J.J., Long, D., Li, F.D., and Zhang, B., 2010, Spatio-temporal variations of $\mathrm{d} 2 \mathrm{H}$ and $\mathrm{d} 18 \mathrm{O}$ in precipitation and shallow groundwater in the Hilly Loess Region of the Loess Plateau, China. Environmental Earth Sciences, v. 63, pp. 1105-1118. doi:10.1007/s12665-010-0785-y.

Lim, H.S., Lee, J.S., Chon, H.T., and Sager, M., 2008, Heavy metal contamination and health risk assessment in the vicinity of the abandoned Songcheon Au-Ag mine in Korea. Journal of Geochemical Exploration, v. 96, pp. 223-230.

Orlando, L.A., and Wu, R.R., 2018, Chapter 1 - Family Health History and Health Risk Assessment For Cardiovascular Disease in Health Care. In: Genomic and Precision Medicine (Third Edition), Ginsburg, G.S., Willard, H.F. (Eds.), Academic Press, pp. 1-16.

Meghdadi, A., and Javar, N., 2018, Quantification of spatial and seasonal variations in the proportional contribution of nitrate sources using a multi-isotope approach and Bayesian isotope mixing model. Environmental Pollution, v. 235, pp. 207-222.

Mekala, C, Nambi, I.M., 2016, Experimental and simulation studies on nitrogen dynamics in unsaturated and saturated soil using HYDRUS2D. Procedia Technol, v. 25, pp. 122-129.

Manassaram, D.M., Backer, L.C., and Moll, D.M., 2006, A review of nitrates in drinking water: maternal exposure and adverse reproductive and developmental outcomes. Environmental Health Perspectives, v. 114, pp. 320-327. doi:10.1289/ehp.8407.

McArthur, J.M., Sikdar, P.K., Hoque, M.A., and Ghosal, U., 2012, Wastewater impacts on groundwater: $\mathrm{Cl} / \mathrm{Br}$ ratios and implications for arsenic pollution of groundwater in the Bengal Basin and Red River Basin, Vietnam. Science Total Environment, v. 437, pp. 390-402.
McQuillan, D., 2004, Ground-water quality impacts from on-site septic systems. Paper presented at the Proceedings. In: National Onsite Wastewater Recycling Association, 13th Annual Conference, Albuquerque, NM.

Mekala, C., and Nambi, I.M., 2016, Transport of Ammonium and Nitrate in Saturated Porous Media Incorporating Physiobio transformations and bioclogging, Bioremediation Journal, v. 20, pp. 117-132.

Miri, M., Akbari, E., Amrane, A., Jafari, S.J., Eslami, H., Hoseinzadeh, E., Zarrabi, M., Salimi, J., Sayyad-Arbabi, M., and Taghavi, M., 2017, Health risk assessment of heavy metal intake due to fish consumption in the Sistan region, Iran. Environmental Monitoring and Assessment, v. 189, pp. 583.

Miri, M., Bhatnagar, A., Mahdavi, Y., Basiri, L., Nakhaei, A., Khosravi, R., Eslami, H., Ghasemi, S.M., Balarak, D., and Alizadeh, A., 2018, Probabilistic risk assessment of exposure to fluoride in most consumed brands of tea in the Middle East. Food and Chemical Toxicology, v. 115, pp. 267-272.

Nemčić-Jurec, J., and Jazbec, A., 2017, Point source pollution and variability of nitrate concentrations in water from shallow aquifers. Application of Water Science, v. 7, pp. 1337. doi:org/10.1007/s13201-015-0369-9.

Omer, A.A.M., 1996, Geological, mineralogical and geochemical studies on the Neogene and Quaternary Nile basin deposits, Qena-Assiut stretch, Egypt. PhD Thesis, Geology Dept, Faculty of Science, Sohag, South Valley Univ 320 p.

Ruiz, P., Yang, X., Lumen, A., and Fisher, J., 2013, Chapter 2 - Quantitative Structure-Activity Relationship (QSAR) Models, Physiologically Based Pharmacokinetic (PBPK) Models, Biologically Based Dose Response (BBDR) and Toxicity Pathways: Computational Tools for Public Health. In: Computational Toxicology, Fowler, B.A. (Ed), Academic Press.

Qasemi, M., Afsharnia, M., Farhang, M., Bakhshizadeh, A., Allahdadi, M., and Zarei, A., 2018a, Health risk assessment of nitrate exposure in groundwater of rural areas of Gonabad and Bajestan, Iran. Environmental Earth Sciences, v. 77, pp. 551.

Qasemi, M., Farhang, M., Biglari, H., Afsharnia, M., Ojrati, A., Khani, F., Samiee, M., and Zarei, A., 2018b, Health risk assessments due to nitrate levels in drinking water in villages of Azadshahr, northeastern Iran. Environmental Earth Sciences, v. 77, pp. 782. doi:org/10.1007/s126650187973-6.

Radfard, M., Yunesian, M., Nabizadeh, R., Biglari, H., Nazmara, S., Hadi, M., Yousefi, N., Yousefi M., Abbasnia A., and Mahvi, A.H., 2018, Drinking water quality and arsenic health risk assessment in Sistan and Baluchestan, Southeastern Province, Iran. Human and Ecological Risk Assessment, v. 24, pp. 1-17.

Redwan, M., and Abdel Moneim, A.A., 2016a, Using Na/K Ratios to Identify the Potential Impacts of Sewage Effluent on Groundwater Quality in Sohag, Egypt. Environmental Monitoring and Assessment, v. 36, pp. $62-70$.

Redwan, M., and Abdel Moneim, A.A., 2016b, Factors controlling groundwater hydrogeochemistry in the area west of Tahta, Sohag, Upper Egypt. Journal African Earth Sciences, v. 118, pp. 328-338.

Redwan, M., Abdel Moneim, A.A., and Amra, M.A., 2016, Effect of waterrock interaction processes on the hydrogeochemistry of groundwater west of Sohag area, Egypt. Arabian Journal of Geosciences, v. 9, pp. 111. doi:org/10.1007/s12517-015-2042-x.

Rivett, M.O., Buss, S.R., Morgan, P., Smith, J.W.N., and Bemment, C.D., 2008, Nitrate attenuation in groundwater: a review of biogeochemical controlling processes. Water Research, v. 42, pp. 4215-4232. doi:org/ 10.1016/j.watres.2008.07.020.

Said, R., 1960, Planktonic foraminifera from the Thebes Formation, Luxor, Egypt. Micropaleontology, v. 16, pp. 227-286.

Said, R., 1975, The Geological evolution of the River Nile. In: Problems in Prehistory of Northern Africa and the Levant. Wendorf F, Maks AF (Eds.), Southern Methodist University Press. Dallas, Texas, pp. 7-44.

Said, R., 1981, The geological evolution of the River Nile. Springer-Verlag, New York 151p. 
Sall, M., and Vanclooster, M., 2009, Assessing the well water pollution problem by nitrates in the small scale farming systems of the Niayes region, Senegal. Agriculture Water Management, v. 96, pp. 1360-1368.

Savard, M.M., 2016, Groundwater nitrate concentration evolution under climate change and agricultural adaptation scenarios: Prince Edward Island, Canada. Earth System Dynamic, v. 7, pp. 183.

Shaharoona, B., Al-Ismaily, S., Al-Mayahi, A., Al-Harrasi, N., Al-Kindi, R., Al-Sulaimi, A., Al-Busaidi, H., and Al-Abri, M., 2019, The role of urbanization in soil and groundwater contamination by heavy metals and pathogenic bacteria: A case study from Oman. Heliyon, doi:org/ 10.1016/j.heliyon.2019.e01771.

Shamrukh, M., Corapcioglu, M.Y., and Hassona, F.A., 2001, Modeling the effect of chemical fertilizers on groundwater quality in the Nile Valley aquifer, Egypt. Groundwater, v. 39, pp. 59-67.

Stumm, W., and Morgan, J.J., 2012, Aquatic Chemistry: Chemical Equilibria and Rates in Natural Waters, vol 126. John Wiley \& Sons.

Swann, P.F., 1975. The toxicology of nitrate, nitrite and N-nitroso compounds. Journal of the Science of Food and Agriculture, v. 26, pp. 1761-1770.

USEPA, 2013, Integrated risk information system (IRIS). United States Environmental Protection Agency, Washington, DC.

Wang, Z., Chai, L., Wang, Y., Yang, Z., Wang, H., and Wu, X., 2011, Potential health risk of arsenic and cadmium in groundwater near Xiangjiang River, China: a case study for risk assessment and management of toxic substances. Environmental Monitoring and Assessment, v. 175, pp. $167-173$

Wang, Z., Jiang, Y., Awasthi, M.K., Wang, J., Yang, X., Amjad, A., Wang, Q., Lahori, A.H., and Zhang, Z., 2018, Nitrate removal by combined hetero-

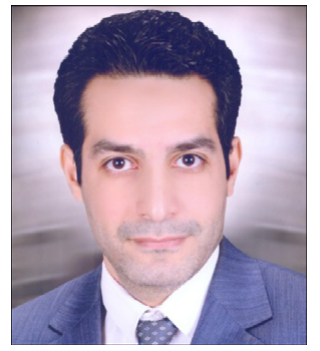

Mostafa Redwan has obtained his $\mathrm{PhD}$ degree in Environmental Geology and mineralogy in 2011 from Hannover University, Germany. He is currently working as an Associate Professor of Environmental Geochemistry in Sohag University, Egypt. His current research interests focus on geochemical and mineralogical characterizations of mine wastes, mine site rehabilitation, water-rock interaction, monuments deterioration, groundwater contamination and remediation strategies.

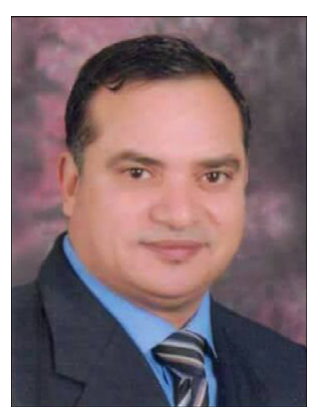

Ahmed A. Abdel Moneim is the president of Sohag University, Egypt. His interests focus on groundwater and surface water environment, hydrogeochemical cycling and groundwater modeling. He has published over 60 research articles including top ranked journals of Elsevier and Springer. trophic and autotrophic denitrification processes: impact of coexistent ions. Bioresource Technology, v. 250, pp. 838-845.

Wei, Y., Fan, W., Wang, W., and Deng, L., 2017, Identification of nitrate pollution sources of groundwater and analysis of potential pollution paths in loess regions: a case study in Tongchuan region, China. Environmental Earth Sciences, v. 76, pp. 423.

WHO, 2011, Guidelines for drinking-water quality: recommendations. World Health Organization, Geneva.

Wogan, G.N., Generoso, W., Koller, L.D., and Smith, R.P., 1995, Nitrate and Nitrite in Drinking Water. Washington, DC: National Academic Press.

Wu, J., Yin, Y., and Wang, J., 2017, Hydrogen-based membrane biofilm reactors for nitrate removal from water and wastewater. The International Journal of Hydrogen Energy, v. 43, pp.1-15.

$\mathrm{Wu}$, J., and Sun, Z., 2016, Evaluation of shallow groundwater contamination and associated human health risk in an alluvial plain impacted by agricultural and industrial activities, mid-west China. Exposure and Health, v. 8, pp. 311-329. doi:10.1007/s12403-015-0170-x.

Xing, M., and Liu, W.G., 2016, Using dual isotopes to identify sources and transformations of nitrogen in water catchments with different land uses, Loess Plateau of China. Environmental Science and Pollution Research, v. 23, pp. 388-401. doi:10.1007/s11356-015-5268-y.

Zhang, Y., Wu, J., and Xu, B., 2018, Human health risk assessment of groundwater nitrogen pollution in Jinghui canal irrigation area of the loess region, northwest China. Environmental Earth Sciences, v. 77, pp. 273.

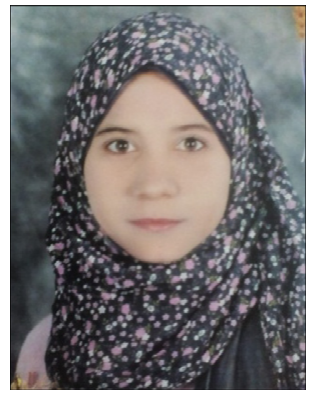

Nagat E. Mohammed is a master student of Hydrogeology at Geology department, Sohag University, Egypt. She completed her B.Sc. degree in Sohag University in 2011.Her interests focus on Hydrogeology.

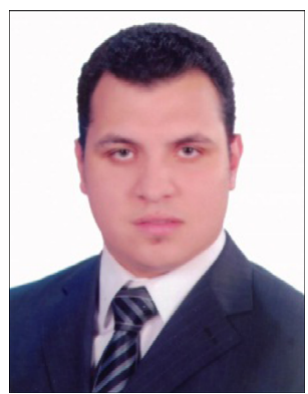

Ahmed M. Masoud is a lecturer and postdoc at Geology Department, Sohag University, Egypt. His research interests involve qualitative and quantitative hydrogeology. He has published many research papers in international and Egyptian journals and conferences. 